\title{
Tourism and Economic Growth Nexus in Latin America and Caribbean Countries: Evidence from an Autoregressive Distributed Lag Panel
}

\author{
José Alberto Fuinhas \\ CeBER, Faculty of Economics, University of Coimbra, Portugal \\ fuinhas@uc.pt \\ Matheus Belucio \\ ISAG - European Business School and Research Group of ISAG (NIDISAG) \\ and CEFAGE-UE, Department of Economics, University of Évora, Portugal, \\ matheus.silva@isag.pt
}

Daniela Castilho

Management and Economics Department, University of Beira Interior, Portugal daniela.castilho@ubi.pt

Joana Mateus

Management and Economics Department, University of Beira Interior, Portugal joana.mateus@ubi.pt

\section{Rafaela Caetano}

Management and Economics Department, University of Beira Interior, Portugal rafaela.caetano@ubi.pt

This research focuses on tourism as a way to stimulate economic growth in Latin America and the Caribbean countries. The impact of tourism on economic growth was expected to have both short- and long-run effects. Panel autoregressive distributed lag, an econometric technique that allows for this temporal decomposition, was used. The results for the twenty-two countries revealed that, in the short-run, tourist capital investment per capita, tourist arrivals (number of persons), per capita electricity consumption, and the real exchange rate were statistically significant and had a positive impact on economic growth. In contrast, in the long-run, only tourist arrivals and per capita electricity consumption proved to be positive drivers of per capita economic growth. Policymakers should continue to develop and implement measures to attract as many tourists as possible while promoting investment in the tourism industry. However, they also need to pay attention to other economic sectors so that their countries do not become extremely dependent on tourism activity.

Keywords: capital investment, tourism arrivals, economic growth, Latin America and Caribbean, ARDL

(cc)BY-SA https://doi.org/10.26493/2335-4194.13.21-34 


\section{Introduction}

Although the economic activity of Latin America and Caribbean countries is still recovering from the impacts of various economic and social crises, the International Monetary Fund (IMF) stated that after 2017 the region's economic growth increased by $1.3 \%, 1.6 \%$ in 2018, and 2019 it is expected to increase by $2.6 \%$ (International Monetary Fund, 2018). These results could mean that these countries can rapidly increase their growth rates. The primary motivation for the achievement of this study was the fact that tourism is a sector in development and has an essential role in the economic growth of this region. Thus, corroborating with World Travel Market (2018), the number of foreign tourists arriving in Latin America increased by 6\% in the previous five years. Moreover, the World Travel and Tourism Council (2018) estimates point to the fact that the travel and tourism sector recently contributed to $15.2 \%$ of the Caribbean Gross Domestic Product, region which is included in the group of countries that we will use in our investigation.

Given the facts previously stated, the characteristics of this region and the particular interest points, tourism becomes quite relevant. Being a fast-growing sector, it is crucial to verify if more tourists and investment (as well as, their efficiency) lead to an increase in economic benefits of Latin American and Caribbean countries. Thus, this theme should continue to be studied.

The impact of tourism on economic growth is an extensively explored theme in the economic growth literature. However, few studies use panel methodology to study the impacts of this sector on the growth of the Latin America and Caribbean region.

In our study, we used 22 countries from the Latin America and Caribbean region, with annual data ranging from 1995 to 2014. The autoregressive distributed lag (A RDL) model was used in our empirical investigation mainly because it supports variables with different orders of integration and gives robust results with small samples. Though the ARDL model, we evaluate the impacts that tourism intensity and tourism capital investment have on the economic growth of Latin America and Caribbean countries on both the short and that long run. To reach this objective, we used annual data on Gross Domestic Product per capita (GDPPC), which is our proxy for economic growth, and on tourism arrivals per capita (TA P C) and tourism capital investment per capita (TIPC) in order to represent the tourism sector.

The main goal of this study is to answer the central question: 'What are the impacts of tourism intensity and tourism capital investment on the economic growth of Latin America and Caribbean countries?' Given the central question of our study, we can construct the two following hypotheses.

$\mathrm{H} 1$ Tourism intensity has a positive impact on economic growth, given that it contributes to employment creation and stimulates the economic activity of the Latin America and Caribbean countries.

$\mathrm{H} 2$ Capital investment has a positive impact on economic growth, given that it contributes to the construction of new infrastructure, technological progress, and innovation in Latin America and Caribbean countries.

In this research, we will attempt to confirm (or not) the validity of these hypotheses as we simultaneously attempt to contribute to the enlargement of the literature on this field.

This study is organised as follows. The second section presents literature reviews about the tourismeconomic growth nexus. The third describes the data, methodology, and preliminary tests. The fourth section presents the results and discussion, and the fifth section concludes the study.

\section{Literature Review}

In this section, essential aspects will be discussed in the literature on tourism economics, focusing on the way tourism relates to the economy and addressing specific aspects of tourism in the Latin American and Caribbean region.

\section{Revisiting Tourism and Economy}

The relationship between tourism development and economic growth has been studied widely in recent years (e.g., Cannonier \& Burke, 2019; Belucio et al., 2018; Brida, Lanzilotta \& Pizzolon, 2016; Du et al., 
2016; Cárdenas-García et al., 2015; Tugcu, 2014) given that the results from this relationship can help some countries to develop effective growth strategies for their economies.

The supply of foreign currency, the promotion of investment, in both infrastructure and human capital, and the jobs that this sector creates are some of the significant benefits from international tourism that can produce positive effects on a country's economic growth. Moreover, following Blake et al. (2016), tourism has an essential role on the increase of the average income of a country, as well as in the increase of both the efficiency and competitiveness of the economies.

Malta et al. (2019) analysed the context that enabled the creation of a vision that attributes to tourism the capacity to reduce poverty. According to the World Tourism Organization (2015), in 2014, one in every eleven jobs around the world was created by the tourism sector, which demonstrates the weight that this sector has on the worldwide economy.

Given the facts previously stated, it is natural that the relationship between tourism and growth has an extensive branch of literature about it. Lanza and Pigliaru (2000) were the pioneers of the investigation of the relationship between these two variables. In their work, they concluded that the countries specialised in tourism shared features, such as tourist destinations of small geographical size, where the average per capita income proliferated.

Moving forward, the analysis of the relationship between tourism and economic growth has at least four hypotheses that can be easily identified in the literature: growth hypothesis also called the tourism-led growth hypothesis (TLGH or TLG): conservation hypothesis; feedback hypothesis; and neutrality hypothesis (e.g., Dogru \& Bulut, 2018). These hypotheses appear in the majority of the causality tests related to economic growth, mainly in energy economics. Nevertheless, this group of hypotheses can be reformulated and used in tourism analysis.

The TLGH, as the name implies, state that tourism development stimulates economic growth: the tourist arrivals and the revenues generated by the tourism sector have a positive impact on economic growth. This hypothesis is supported by the majority of the authors that focus their works on the assessment of this relationship (e.g., Shahzad et al., 2017; Tugcu, 2014; Husein \& Kara, 2011; Cortes-Jimenez \& Pulina, 2010).

Regarding the conservation hypothesis (e.g., Aslan, 2014; Payne \& Mervar, 2010), while this hypothesis asserts that the economic output of a country can induce tourism development, it also suggests that deterioration on the economic performance of a country can significantly reduce its tourism demand.

Concerning the feedback hypothesis (e.g., Rivera, 2017; Al-mulali et al., 2014; Massidda \& Mattana, 2013), it considers economic growth and tourism development to be complementary and strongly dependent. This hypothesis is the same as saying that economic growth promotes tourism development as well as the other way around.

Finally, the neutrality hypothesis (e.g., Katircioglu, 2009) suggests that there is no relationship between tourism development and economic growth: they are entirely independent. This hypothesis indicates that, for example, strategies for tourism development (e.g., investing in the tourism sector) do not produce direct effects on economic growth.

Besides these four hypotheses, there is an additional one: the curse hypothesis, or the beach disease effect (e.g., Holzner, 2011). This hypothesis can be defined as follows: countries in which the tourism sector plays a significant role in their economies (tourismdependent countries) tend to grow less than the others do.

Turning to the methodological part of the works on the tourism-growth nexus, in the literature, many variables were used as tourism proxies. The most commonly used are international tourism revenues (e.g., Durbarry, 2004; Balaguer \& Cantavella-Jordà, 2002), number of tourist arrivals (e.g., Zortuk, 2009; Gunduz \& Hatemi-J, 2005), tourism specialization (e.g., Algieri, 2006), tourism industries (e.g., Tang \& Shawn, 2009), and tourism spending (e.g., Nissan et al., 2011), for example. As expected, the variable Gross Domestic Product is the one that researchers use the most often to measure economic growth.

Regarding the empirical methodologies that are used to investigate the relationship between tourism 
and economic growth, it can be emphasized that they differ from author to author. However, there are two main methodological approaches: panel data estimations, and time-series estimations. Brida et al. (2016) made a detailed review of the empirical methods that were applied in the literature close to this theme, and their advantages and disadvantages.

The panel data models are frequently preferred because they allow doing a simultaneous analysis of the cross-sectional and temporal dimensions. The panel Granger causality techniques (e.g., Belucio et al., 2018; Al-mulali et al., 2014) and the autoregressive distributed lag model (A RDL) (e.g., Katircioglu, 2009) are some of the estimation methods that are more frequently used in this type of studies.

\section{The Region}

Latin America has been experiencing significant changes in recent decades (Bianchi et al., 2018). Tourism has grown in most Latin American and Caribbean countries. Researchers and policymakers have long recognised the significance of tourism to the Caribbean region (Cannonier \& Burke, 2019)

The region has two of the seven natural wonders of the world, and three of the seven wonders of the modern world. Tourism in the region has diversified effects, whether micro or macroeconomics. Garza and Ovalle (2019) argue that tourism-driven development affects the spatial distribution of prices and increasing daily transportation difficulties.

Focusing on the Latin America and Caribbean countries (LAC), we can refer that for these countries the tourism literature is quite extensive (e.g., Belucio et al., 2018; Risso \& Brida, 2008; Brida et al., 2008; Eugenio-Martin et al., 2004). The conclusions of the works focused on the relationship between tourism and growth in this region, or in some countries of the LAC, predominantly support the TLGH. Before we conclude, we also should refer that the reasons cited in the literature to the differences in the study's results are mainly the fact that authors usually apply different empirical methodologies, and chose different periods and samples to be analysed (e.g., Dogru \& Bulut, 2018).

Even though most of the studies show that tourism development has positive impacts on the economic output of the countries, the results are far from conclusive, and for that reason, we support the idea that this relationship should continue to be extensively studied.

The assessment of the impacts that tourism have on growth is especially crucial for the case of Latin America and Caribbean countries because they have a set of characteristics (e.g., cultural and natural wealth) that make them a choice destination for tourists from all over the world. However, tourism safety in Latin America has not evolved to the same level in all Latin American countries (Maximiliano, 2014).

Some of the critical factors that can deter tourists from a destination are the security of the destination and the exchange rate. Regarding the safety of tourists in Latin America, the central issue is related to local crime (Maximiliano, 2014). However, the development of sound public regulation can generate economic growth and benefits for tourism agents, which is reflected in improvements for the population (Belucio et al., 2018) and tourists.

The exchange rate plays an essential role in the lives of underdeveloped or in the development of tourist destinations. The inflow of foreign capital is responsible for economic growth, but policymakers often neglect the exchange rate policies (Dogru et al., 2019), which can have a significant impact on the trade balance. It is also known that the real effective exchange rate has significant effects on economic growth (Lee \& Chang, 2008) and that exchange variation can benefit or hurt a tourist destination.

\section{Data and Methodology}

Our study is focused on the assessment of the impacts of tourism on the economic growth of a group of Latin America and Caribbean: Argentina, Bolivia, Brazil, Chile, Colombia, Costa Rica, Cuba, Dominican Republic, Ecuador, El Salvador, Guatemala, Haiti, Honduras, Jamaica, Mexico, Nicaragua, Panama, Paraguay, Peru, Trinidad and Tobago, Uruguay and Venezuela. For the present investigation, we will use annual data from 1995 to 2014. Both the time horizon and countries were chosen, given the available data. In this study, we used STATA 15.0 to perform our econometric analysis. In Table 1 the name, definition, and source of our variables are presented. 
Table 1 Variables Description

\begin{tabular}{|c|c|c|}
\hline Variable & Definition & Source \\
\hline GDP & $\begin{array}{l}\text { Gross Domestic Product in } \\
\text { a constant local currency } \\
\text { unit }\end{array}$ & World Bank \\
\hline $\mathrm{P}$ & $\begin{array}{l}\text { The total population in the } \\
\text { total number of persons }\end{array}$ & World Bank \\
\hline EPC & $\begin{array}{l}\text { Electric power consumption } \\
\text { in GWh }\end{array}$ & World Bank \\
\hline TA & $\begin{array}{l}\text { Tourism arrivals in the } \\
\text { number of persons }\end{array}$ & World Bank \\
\hline GDP_US & $\begin{array}{l}\text { Gross Domestic Product in } \\
\text { constant } 2010 \text { US\$ }\end{array}$ & World Bank \\
\hline TI & $\begin{array}{l}\text { Capital Investment in a } \\
\text { constant local currency unit }\end{array}$ & $\begin{array}{l}\text { World Travel \& } \\
\text { Tourism Council }\end{array}$ \\
\hline $\mathrm{TX}$ & Real exchange rate & $\begin{array}{l}\text { Author's calcu- } \\
\text { lation from the } \\
\text { World Bank }\end{array}$ \\
\hline
\end{tabular}

The dependent variable will be Gross Domestic Product in constant local currency (GDP), our proxy for economic growth.

To measure tourism intensity, the ratio of the tourism arrivals (TA), by the total population (P) was used. The tourism capital investment ( $\mathrm{TI}$ ), which represents the capital investment spending by all industries directly involved in travel and tourism, is another of our interest variables and will also be divided by the total population (P). We choose the electric power consumption (EPC) as our control variable because the energy use of a country is highly correlated with its economic growth (e.g., Santiago et al., 2020); furthermore, energy can contribute to the three dimensions of development: social, economic and human (e.g., Malaquias et al., 2019). The Gross Domestic Product was also retrieved in constant 2010 US\$, in order to calculate the real exchange rate ( $\mathrm{Tx})$ through the ratio of Gross Domestic Product in constant local currency by the Gross Domestic Product in constant 2010 US\$.

The transformation of the variables into per capita values is essential because it eliminates the dimensional distortions caused in the model's estimations by the variables in levels. GDP, EPC, TA, GDP_US, and P, were all retrieved from the World Bank, while TI was retrieved from the World Travel \& Tourism Council.

We will use the autoregressive distributed lag (ARDL) model in the form of an Unrestricted Error Correction Mechanism (UECM). This methodology gives the dynamic effects of the variables, allowing us to make a distinction between the Granger causality in short and the long-run. Moreover, it is robust to the presence of endogeneity, and when a determined coefficient is statistically significant, it is equivalent to the Granger causality testing (Menegaki et al., 2017; Jouini, 2015). Additionally, it deals with cointegration and supports the inclusion of variables with different orders of integration (I(o), I(1), and fractionally integrated variables) in the same estimation. The variables were transformed into natural logarithms ('L') and first differences (' $D$ '). The ARDL model specification is the following:

$$
\begin{aligned}
\operatorname{LGDPPC}_{i t}= & \alpha_{1 i}+\delta_{1 i} \mathrm{TREND}_{1 i 1} \beta_{1 \mathrm{LGDPPC}_{i t-1}} \\
& +\beta_{1 i 2} \mathrm{LTAPC}_{i t}+\beta_{1 i 3} \mathrm{LTAPC}_{i t-1} \\
& +\beta_{1 i 4} \mathrm{LTIPC}_{i t}+\beta_{1 i 5} \mathrm{LTIPC}_{i t-1} \\
& +\beta_{1 i 6} \mathrm{LEPC}_{i t}+\beta_{1 i 7} \mathrm{LEPC}_{i t-1} \\
& +\beta_{1 i 8} \mathrm{TX}_{i t}+\beta_{1 i 9} \mathrm{TX}_{i t-1}+\beta_{1 i t} .
\end{aligned}
$$

To explain the dynamic relationships between our variables, we reparametrized equation (1) into the following specification:

$$
\begin{aligned}
\operatorname{DLGDPPC}_{i t}= & \alpha_{i}+\beta_{2 i 1} \mathrm{DLTAPC}_{i t}+\beta_{2 i_{2} \mathrm{DLTIPC}_{i t}} \\
& +\beta_{2 i 3} \mathrm{DLEPC}_{i t}+\beta_{2 i_{4} \mathrm{DLTX}_{i t}} \\
& +\gamma_{2 i 1} \mathrm{LGDPPC}_{i t-1}+\gamma_{2 i 2} \mathrm{LTAPC}_{i t-1} \\
& +\gamma_{2 i 3} \mathrm{LTIPC}_{i t-1}+\gamma_{2 i 4} \mathrm{LEPC}_{i t-1} \\
& +\gamma_{2 i 5} \mathrm{TX}_{i t-1}+\varepsilon_{2 i t} .
\end{aligned}
$$

A series of diagnostic tests before the estimation are necessaries to validate that the choice of method was accurate. In addition, other tests and statistics need to be verified after model estimation to make sure that it meets mandatory econometric requirements in panel analysis (e.g., Dogru et al., 2019; Santiago et al., 202O; Marques et al., 2017; Fuinhas \& Marques, 2012; Katircioglu, 2009). Every test and statistics of the method used will be presented.

In sequence, the characteristics of the series through 
Table 2 Descriptive Statistics and Cross-Sectional Dependence

\begin{tabular}{|c|c|c|c|c|c|c|c|c|}
\hline \multirow[t]{2}{*}{ Variables } & \multicolumn{5}{|c|}{ Descriptive statistics } & \multicolumn{3}{|c|}{ Cross section dependence (CD) } \\
\hline & Obs & Mean & Std. dev. & Min. & Max. & CD-test & Corr & $\operatorname{Abs}($ corr $)$ \\
\hline LGDPPC & 439 & 10.636 & 2.717 & 7.191 & 16.194 & $45.25^{\star * *}$ & 0.664 & 0.781 \\
\hline LTAPC & 440 & -2.227 & 1.045 & -4.554 & -0.169 & $39.41^{\star * *}$ & 0.581 & 0.620 \\
\hline LTIPC & 440 & -13.571 & 2.657 & -18.376 & -8.427 & $26.41^{\star * *}$ & 0.390 & 0.524 \\
\hline LEPC & 440 & 6.966 & 1.017 & 3.161 & 8.873 & $44.95^{\star * *}$ & 0.661 & 0.805 \\
\hline LTX & 439 & 2.184 & 2.546 & -1.953 & $7 \cdot 306$ & -0.29 & 0.661 & 0.805 \\
\hline DLGDPPC & 417 & 0.021 & 0.035 & -0.126 & 0.150 & $23.06^{\star * *}$ & 0.348 & 0.378 \\
\hline DLTAPC & 418 & 0.039 & 0.139 & -0.812 & 1.258 & $10.71^{\star * *}$ & 0.161 & 0.237 \\
\hline DLTIPC & 418 & 0.054 & 0.236 & -0.859 & 1.059 & $14.47^{\star * *}$ & 0.219 & 0.313 \\
\hline DLEPC & 418 & 0.029 & 0.075 & -0.508 & 0.538 & $4 \cdot 77^{* * *}$ & 0.072 & 0.213 \\
\hline DLTX & 417 & 0.000 & 0.004 & -0.038 & 0.051 & -1.02 & -0.016 & 0.213 \\
\hline
\end{tabular}

Notes To achieve the results of descriptive statistics and to test the presence of cross-section dependence, the Stata commands sum and $x t c d$, respectively, were used. The $\mathrm{CD}$ test has $N(\mathrm{o}, 1)$ distribution under the Ho: cross-section independence; *** denote statistical significance at $1 \%$ level.

the descriptive statistics as well as the results from the cross-section dependence test are presented. As can be observed, GDPPC has one less observation (data on GDP fails for Haiti in 1995), but that is not a problem, because STATA 15.0 can correct this issue and continues to assume the panel to be a strongly balanced one. It is also possible to observe one less observation on $\mathrm{TX}$ because the variable was calculated using the GDP, and it is not a concern due to the same explanation. As previously stated, in Table 2 , the results from the crosssection dependence test can be observed, where it can be concluded that cross-section dependence is present in all variables, except in real exchange rate (тx).

Next, the correlation matrices and variance inflation factor (VIF) statistics are examined. The correlation matrix was used to check the degree of correlation that exists between the variables, while the VIF statistics was used to test for the presence of multicollinearity. The results of the correlation matrix only indicated the existence of a high level of correlation between LTIPC and LGDPPC, which is not a concern, given that the high correlation is with the dependent variable. A similar situation (high correlation between the LTX and LGDPPC) is detected; again, this does not cause a problem for the estimation due to the same reason. The lower VIF and mean VIF values prove that
Table 3 Correlation Matrices and vif Statistics

\begin{tabular}{lrrrrr}
\hline & LGDPPC & LTAPC & LTIPC & LEPC & LTX \\
\hline LGDPPC & 1.000 & & & & \\
LTAPC & 0.328 & 1.000 & & & \\
LTIPC & 0.753 & 0.069 & 1.000 & & \\
LEPC & 0.364 & 0.449 & 0.409 & 1.000 & \\
LTX & 0.960 & 0.255 & 0.662 & 0.112 & 1.000 \\
\hline VIF $^{*}$ & n.a. & 2.70 & 1.59 & 1.85 & 2.36 \\
\hline & DLGDPPC & DLTAPC & DLTIPC & DLEPC & DLTX \\
\hline DLGDPPC & 1.000 & & & & \\
DLTAPC & 0.352 & 1.000 & & & \\
DLTIPC & 0.366 & 0.234 & 1.000 & & \\
DLEPC & 0.290 & 0.092 & 0.117 & 1.000 & \\
DLTX & 0.191 & -0.024 & 0.044 & 0.026 & 1.000 \\
\hline VIF ${ }^{*}$ & n.a. & 1.07 & 1.07 & 1.02 & 1.00 \\
\hline
\end{tabular}

Notes ${ }^{\star}$ Mean VIF 2.12. ${ }^{* *}$ Mean VIF 1.04.

multicollinearity is not a problem for this paper's estimation. Details are in the Table 3.

Because cross-sectional dependence seems not to be present on the real exchange rate ( $\mathrm{TX}$ ), the 1st generation panel unit root tests will also be computed. Next, the results of the Maddala and Wu test are presented in 
Table 4 Maddala and Wu Panel Unit Roots Test (Mw)

\begin{tabular}{|c|c|c|}
\hline \multirow[t]{2}{*}{ Variable } & \multicolumn{2}{|c|}{ ш в (Zt-bar) } \\
\hline & Without trend & With trend \\
\hline LGDPPC & $124.273^{\star * *}$ & $103.006^{* * *}$ \\
\hline LTAPC & $62.064^{*}$ & 54.967 \\
\hline LTIPC & $63.009^{\star}$ & $92.398^{\star * *}$ \\
\hline LEPC & 39.485 & 32.364 \\
\hline LTX & $157.245^{* * *}$ & $103.039^{\star * *}$ \\
\hline DLGDPPC & $124.273^{\star \star \star}$ & $103.006^{\star * *}$ \\
\hline DLTAPC & $135.209^{* * *}$ & $101.564^{\star * *}$ \\
\hline DLTIPC & $219.515^{\star * *}$ & $159.999^{\star * *}$ \\
\hline DLEPC & $190.021^{\star \star *}$ & $203.790^{\star * *}$ \\
\hline DLTX & $434.253^{\star * *}$ & $388.412^{* * *}$ \\
\hline $\begin{array}{l}\text { Notes }{ }^{*},{ }^{*} \\
\text { level, respec } \\
\text { Test (MW) a } \\
\text { Ho: series is } \\
\text { multipurt wa }\end{array}$ & $\begin{array}{l}\text { tatistical significan } \\
\text { ddala and Wu (1999 } \\
\text { at cross-sectional it } \\
\text { mpute this test, th }\end{array}$ & $\begin{array}{l}\text { at } 10 \% \text { and } 1 \% \\
\text { Panel Unit Root } \\
\text { ependence, and } \\
\text { Stata command }\end{array}$ \\
\hline
\end{tabular}

Table 4. As the test of Maddala and Wu (1999) shows that there are variables presenting cross-sectional dependence, the veracity of the results is compromised for them. Thus, only the order of integration of the $\mathrm{TX}$ variable will be analysed. The result seems to indicate that the variable is $\mathrm{I}(\mathrm{o})$.

To see the order of integration of the remaining variables, the and generation unit root tests, namely the augmented cross-sectional IPS (CIPs) test by (Pesaran, 2007) were computed. This test was used because the presence of cross-sectional dependence was registered in most of the variables, and the 1st generation panel unit root tests turned out to be inefficient in these cases. The results of the Cips test show that some variables are I(1) and others are I(o), which is not a problem because the ARDL model supports these two levels of integration. These results confirm that the ARDL methodology is the best approach for the study (Table 5).

The Hausman test confronts random and fixed effects, and when the structure of the data is in the panel, it is necessary to test for the individual effects. In sequence, the results of the Hausman test are presented and, as we can be observed, the test rejects the null hy-
Table 5 Panel Unit Root test (CIPs)

\begin{tabular}{|c|c|c|}
\hline \multirow[t]{2}{*}{ Variable } & \multicolumn{2}{|c|}{ Cips (Zt-bar) } \\
\hline & Without trend & With trend \\
\hline LGDPPC & -0.415 & 0.734 \\
\hline LTAPC & $-2.368^{\star * *}$ & -0.810 \\
\hline LTIPC & $-4.151^{\star * *}$ & $-2.741^{\star * *}$ \\
\hline LEPC & -0.185 & 3.613 \\
\hline LTX & $-6.137^{* * *}$ & $-4.030^{\star * *}$ \\
\hline DLGDPPC & $-3.435^{* * *}$ & $-2.761^{\star * *}$ \\
\hline DLTAPC & $-3.293^{* * *}$ & $-2.233^{\star * *}$ \\
\hline DLTIPC & $-6.388^{\star * *}$ & $-4.385^{* * *}$ \\
\hline DLEPC & $-5.198^{\star * *}$ & $-5.945^{* * *}$ \\
\hline DLTX & $-10.958^{\star * *}$ & $-8.922^{\star * *}$ \\
\hline \multicolumn{3}{|c|}{$\begin{array}{l}\text { Notes }{ }^{* *} \text { denote statistical significance at } 1 \% \text { level; Pesaran } \\
(2007) \text { Panel Unit Root Test (CIPS) assumes that cross- } \\
\text { sectional dependence is in the form of a single unobserved } \\
\text { common factor and Ho: series is I(1); to compute this test, } \\
\text { the Stata command multipurt was used. }\end{array}$} \\
\hline
\end{tabular}

Table 6 Hausman Test

\begin{tabular}{|c|c|}
\hline Test & FE VS RE \\
\hline Hausman test & $\chi^{2}(8)=48.46^{\star * *}$ \\
\hline
\end{tabular}

pothesis. This result led us to conclude that the fixed effects model is the proper specification for our estimation: the countries' individual effects are significant. In this estimation, the sigmamore option was used, which is a recurrent option in previous studies (e.g., Özokcu \& Özdemir, 2017) (Table 6).

After the Hausman test, with the results pointing to the use of the fixed effects model, the next step is the execution of a group of specification tests. The results of the pre-tests still reveal details of the nature of the variables, information useful for models' estimation.

\section{Results and Discussion}

To test for the presence of heteroscedasticity, we computed the modified Wald Test (null hypothesis: Homoscedasticity). The Pesaran test (null hypothesis: 
Table 7 Specification Tests

\begin{tabular}{lr}
\hline Test & \multicolumn{1}{c}{ Statistics } \\
\hline Modified Wald test & $354.940^{\star * *}$ \\
Pesaran's test & $11.197^{\star * *}$ \\
Wooldridge test & $59.396^{\star * *}$ \\
\hline
\end{tabular}

Notes Ho of Modified Wald test: $\sigma(i)^{2}=\sigma^{2}$ for all $i$; Ho of Pesaran's test: residual are not correlated; Ho of Wooldridge test: no first-order autocorrelation; ${ }^{* * *}$ denotes statistical significance at $1 \%$ level.

residuals are not correlated and follow a normal distribution) to check for the presence of contemporaneous correlation was used. The Breush-Pagan Lagrangian multiplier test was also used to test if the variances across individuals are not correlated. In the present case, this test could not be applied because the number of countries in that sample is larger than the number of years in the study. Lastly, the Wooldridge test was used for autocorrelation to assess for the presence of serial correlation in our model.

The results from the previously mentioned tests are presented in Table 7 , showing that heteroscedasticity, contemporaneous correlation, and first-order autocorrelation are all present in the model. All the statistics reject the null hypothesis of the respective specification tests.

Given these results, the Driscoll and Kraay (1998) estimator is the most appropriate estimator to use in estimations, because the standard errors produced by the estimator are robust to disturbances being crosssectional dependent, heteroskedastic and autocorrelated up to some lag.

In this model, both the trend, the tourism capital investment per capita, and the real exchange rate (both $\mathrm{TI}$ and $\mathrm{Tx}$ on the long-run) were statistically insignificant and were thus retrieved from the model. After these conclusions, equation (2) was replaced by equation (3), which represents this more parsimonious model.

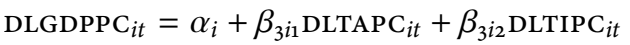

$$
\begin{aligned}
& +\beta_{3 i 3} \mathrm{DLEPC}_{i t}+\beta_{3{ }_{i}{ }_{4} \mathrm{DLTX}_{i t}} \\
& +\gamma_{3 i_{1} \mathrm{LGDPPC}_{i t-1}}+\gamma_{3 i_{2} \mathrm{LTAPC}_{i t-1}} \\
& +\gamma_{3 i 3} \mathrm{LEPC}_{i t-1}+\varepsilon_{i t} \text {. }
\end{aligned}
$$

Table 8 Estimation Results (Dependent Variable: DLGDPPC)

\begin{tabular}{lcc}
\hline Variable & FE & FE-D K \\
\hline Constant & $0.722^{* * *}$ & $0.722^{* * *}$ \\
DLTAPC & $0.084^{* * *}$ & $0.084^{* * *}$ \\
DLTIPC & $0.035^{* * *}$ & $0.035^{* * *}$ \\
DLEPC & $0.099^{* * *}$ & $0.099^{* * *}$ \\
DLTX & $1.694^{* * *}$ & $1.694^{* * *}$ \\
LGDPPC $(-1)$ & $-0.076^{* * *}$ & $-0.076^{* * *}$ \\
LTAPC $(-1)$ & $0.036^{* * *}$ & $0.036^{* * *}$ \\
LEPC $(-1)$ & $0.026^{* * *}$ & $0.026^{*}$ \\
\hline Diagnostic statistics & & \\
$N$ & 417 & 417 \\
$R^{2}$ & 0.373 & 0.373 \\
$F$ & $3(7,388)=33.04^{* * *} F(7,18)=27.91^{* * *}$ \\
\hline
\end{tabular}

Notes ${ }^{* * *},{ }^{*}$ denote statistical significance at $1 \%$ and $10 \%$ level, respectively; to estimate the models, the Stata command $x t s c c$ was used.

Specification tests were remade for the parsimonious model, and the results were in line with the previous ones (presence of heteroscedasticity, autocorrelation. and contemporaneous correlation in the model). The results of the estimations are presented in detail in Table 8 . The results show that, in the shortrun, the tourism intensity, the tourism capital investment per capita, the electric energy consumption per capita, and the real exchange rate are all positive and statistically significant. Table 8 also shows a positive and statistically significant impact of both tourism intensity and electric power consumption on economic growth in the long-run. As we previously stated, the tourism capital investment and real exchange rate failed to show a statistically significant impact in the long-run and, for that reason, it was excluded from the estimation.

The long-run elasticities are not displayed in Table 8 because they had to be calculated through the ratio between the variable's coefficient and the LGDPPC coefficient, both lagged once, and this ratio was multiplied by -1 . In Table 9, the impacts (short-run), elasticities (long-run), and the adjustment speed of the model (ЕСM) are shown. 
Table 9 Elasticities and Speed of Adjustment (Dependent Variable: DLGDPPC)

\begin{tabular}{|c|c|c|}
\hline Variable & $\mathrm{FE}$ & FE-DK \\
\hline \multicolumn{3}{|c|}{ Short-run impacts } \\
\hline DLTAPC & $0.084^{* * *}$ & $0.084^{* *}$ \\
\hline DLTIPC & $0.035^{* * *}$ & $0.035^{* *}$ \\
\hline DLEPC & $0.099^{* * *}$ & $0.099^{* *}$ \\
\hline DLTX & $1.694^{\star * *}$ & $1.694^{* *}$ \\
\hline \multicolumn{3}{|c|}{ Long-run (computed) elasticities } \\
\hline LTAPC & $0.471^{* * *}$ & $0.471^{\star *}$ \\
\hline LEPC & $0.345^{* * *}$ & $0.345^{* *}$ \\
\hline \multicolumn{3}{|c|}{ Speed of adjustment } \\
\hline ECM & $-0.076^{* * *}$ & $-0.076^{\star *}$ \\
\hline
\end{tabular}

Notes ${ }^{* * *}$ denote statistical significance at $1 \%$ level, the ECM denotes the coefficient of the variable LGDPPC lagged once.

From Table 9, it can be seen that the Latin America and Caribbean countries' economic growth was positively affected by the tourism arrivals per capita (tourism intensity) and by the electric power consumption per capita, both in the short and long runs, while the positive effects of tourism capital investment per capita and real exchange rate were only detected in the short run.

Latin America and Caribbean countries suffer from serious political, economic and social problems and therefore, once these problems had an impact on the economic growth of these countries, we considered the relevant shocks, which affected their economies between 1995 and 2014.

In 1997, the Mexican government adopted the $\mathrm{Na}$ tional Program for Development Finance (N P F D F). In Uruguay, in 2002, a bank crisis occurred, due to the country's over-dependence on Argentina, which was also in depression. This depression was mainly due to currency devaluation. In the Dominican Republic, in 2003, a financial crisis was caused by bank failure.

In Venezuela, the oil strike in 2002-2003 followed in 2004 with an impressive rise in the oil prices. Trinidad and Tobago are very dependent on exports; in $2003 \mathrm{~m}$ this country registered a massive increase in GDP, which could be associated with the Venezuelan
Table 10 Estimation Results (Corrected for Shocks, Dependent Variable: DLGDPPC)

\begin{tabular}{|c|c|c|}
\hline Variable & $\mathrm{FE}$ & FE-DK \\
\hline Constant & $0.732^{\star * *}$ & $0.732^{* * *}$ \\
\hline DLTAPC & $0.069^{* * *}$ & $0.069^{* * *}$ \\
\hline DLTIPC & $0.034^{* * *}$ & $0.034^{* * *}$ \\
\hline DLEPC & $0.092^{* * *}$ & $0.092^{* * *}$ \\
\hline DLTX & $1.708^{\star * *}$ & $1.708^{\star * *}$ \\
\hline LGDPPC $(-1)$ & $-0.075^{* * *}$ & $-0.075^{* * *}$ \\
\hline LTAPC $(-1)$ & $0.028^{* * *}$ & $0.028^{* * *}$ \\
\hline $\operatorname{LTIPC}(-1)$ & 0.004 & $0.004^{* *}$ \\
\hline $\operatorname{LEPC}(-1)$ & $0.029^{* * *}$ & $0.029^{* *}$ \\
\hline A RG 2002 & $-0.129^{* * *}$ & $-0.129^{* * *}$ \\
\hline ARG 2009 & $-0.079^{* * *}$ & $-0.079^{* * *}$ \\
\hline Св 2005 & $0.064^{* * *}$ & $0.064^{* * *}$ \\
\hline СВ 2006 & $0.071^{\star * *}$ & $0.071^{\star * *}$ \\
\hline RD 2003 & $-0.062^{\star * *}$ & $-0.062^{* * *}$ \\
\hline H 2009 & $-0.052^{\star *}$ & $-0.052^{* * *}$ \\
\hline MEX 1997 & $0.058^{\star *}$ & $0.058^{* * *}$ \\
\hline MEX 2009 & $-0.079^{\star * *}$ & $-0.079^{* * *}$ \\
\hline Т T 2003 & $0.067^{* * *}$ & $0.067^{* * *}$ \\
\hline Т T 2006 & $0.101^{* * *}$ & $0.101^{* * *}$ \\
\hline T T 2009 & $-0.075^{x * *}$ & $-0.075^{* * *}$ \\
\hline UR 2002 & $-0.084^{\star * *}$ & $-0.084^{* * *}$ \\
\hline VEN 2002 & $-0.087^{* * *}$ & $-0.087^{* * *}$ \\
\hline VEN 2003 & $-0.068^{\star * *}$ & $-0.068^{* * *}$ \\
\hline VEN 2004 & $0.101^{* * *}$ & $0.101^{* * *}$ \\
\hline
\end{tabular}

Diagnostic statistics

$\begin{array}{lrr}N & 417 & 417 \\ R^{2} & 0.586 & 0.586\end{array}$

$F \quad F(23,372)=22.90^{* * *} F(23,18)=940114.75^{* * *}$

Notes ${ }^{* * *}$ and ${ }^{* *}$ denote statistical significance at $1 \%$ or $5 \%$ level, respectively; to estimate the models, the Stata command $x t s c c$ was used.

instability in the same year, which led to a search for a new hydrocarbon exporting country, which benefitted Trinidad and Tobago.

In 2006, Trinidad and Tobago, due to a rise in the oil and gas prices and an increase in the foreign direct investment (FDI), expanded their energy sector. 
Table 11 Impacts, Elasticities and Speed of Adjustment (Model Corrected for Shocks, Dependent Variable: DLGDPPC)

\begin{tabular}{|c|c|c|}
\hline Variable & $\mathrm{FE}$ & FE-DK \\
\hline \multicolumn{3}{|c|}{ Short-run impacts } \\
\hline DLTAPC & $0.069^{* * *}$ & $0.069^{* * *}$ \\
\hline DLTIPC & $0.034^{* * *}$ & $0.034^{* * *}$ \\
\hline DLEPC & $0.092^{* * *}$ & $0.092^{* * *}$ \\
\hline DLTX & $1.708^{\star * *}$ & $1.708^{* * *}$ \\
\hline \multicolumn{3}{|c|}{ Long-run (computed) elasticities } \\
\hline LTAPC & $0.368^{\star * *}$ & $0.377^{* * *}$ \\
\hline LTIPC & 0.047 & $0.057^{* *}$ \\
\hline LEPC & $0.418^{\star * *}$ & $0.385^{* * *}$ \\
\hline \multicolumn{3}{|c|}{ Speed of adjustment } \\
\hline $\mathrm{ECM}$ & $-0.075^{* * *}$ & $-0.075^{* * *}$ \\
\hline
\end{tabular}

In 2005, Cuba had a development of the tourism sector and was registered a reduction in the unemployment rate. In 2006, the highest economic growth in the history of Cuba happened as a result of Cuba's so-called energy revolution (e.g., Suárez et al., 2012). Other shocks that were considered were in Argentina, Haiti, Mexico and Trinidad and Tobago (all in 2009) and that can be due to the financial crisis of 2008 followed by a global recession. Details in Table 10.

What was said previously about some economic problems in these countries indicates the existence of outliers in Argentina (2002), Cuba (2005, 2006), the Dominican Republic (2003), Mexico (1997), Trinidad and Tobago (2003, 2006), and Venezuela (2002, 2003, 2004). To control the detected outliers, dummies were added on the model to represent these events and correct them. Dummies ARG2002, ARG 2009, RD2003, H2009, MEX2009, TT2009, UR2002, VEN2002, and VEN2003 represent a break, while Св 2005, Св 2006, MEX1997, T T 2003, T T 2006 and VEN2004 represents a peak. In Table 11, the impacts, elasticities and speed of adjustment of the model are shown.

From Table 11, it can be seen that the Latin America and Caribbean countries economic growth was positively affected by the tourism arrivals per capita (tourism intensity) and by the electric power consumption per capita, both in the short and long run. After the correction of the shocks, the tourism investment per capita has become statistically significant, not only on the short-run but also in the long-run. In addition, it had a positive impact on economic growth, becoming one of its main drivers. The real exchange rate has a significant and positive impact on economic growth but only in the short-run.

Regarding the ECM, from Table 11, it can be seen that its coefficient is negative and statistically significant, which indicates the presence of long-memory between the variables. This value represents the speed of adjustment of the model, i.e., the speed at which the dependent variable returns to equilibrium after changes in our independent variables. As can be observed, the speed of adjustment of the model is relatively slow.

The positive impacts of the electric power consumption per capita on the economic growth of these countries, both in the short and long-run, were expected, given that energy is seen as a driving force for growth (e.g., Hatemi-J \& Irandoust, 2005). Additionally, it has high explanatory power in empirical growth models. Moreover, many authors consider energy variables crucial to explain countries' economic growth (e.g., Toman \& Jemelkova, 2003). The real exchange rate, as previously stated, had a positive impact on the economic growth in the short run. The importance of the exchange rate to the policy and economic growth could benefit the countries that were in the early stages of economic development (Habib et al., 2017). Thus, because the countries used in this investigation are developing countries, this impact was expected. In the long run, with countries becoming more developed and prosperous, the real exchange rate could become irrelevant to growth (Aghion et al., 2009).

Given these results, the policymakers from Latin America and the Caribbean should be cautious in the adoption of energy conservation policies, since the economic output of these countries seems to be strongly linked with energy consumption, in the present case, with the electric power consumption per 
capita. Measures that lead to a reduction in its consumption appear to be able to affect the economic growth of Latin America and Caribbean countries adversely.

Regarding the central question of the present study, it can be seen that both variables (tourism intensity and tourism capital investment) seem to have had a positive impact on growth, which confirms both of the hypotheses. The results of this study also corroborate those of other authors that studied the relationship between the tourism sector and economic growth for some countries from this region (e.g., Shahzad et al., 2017; Tang \& Abosedra, 2014; Amaghionyeodiwe, 2012).

Given these results, we think that the countries from our sample should continue to attract as many tourists as possible at the same time, while the industries directly involved in travel and tourism should continue to increase the levels of their investments, given that both factors have a positive impact on economic growth. This is congruent with the findings of Du et al. (2016) that tourism's contribution to the longrun growth of an economy comes through its role as an integral part of a broader development strategy.

\section{Conclusion}

In order to answer to the central question of this study, the autoregressive distributed lag (A R DL) model was used to assess the impacts, in both the short and long-run, of tourism on the economic growth of 22 Latin America and Caribbean countries. The specification tests showed that cross-sectional dependence, heteroscedasticity, contemporaneous correlation, and first-order autocorrelation were present in the model, which led to the Discroll Kraay estimator with fixed effects being used. The Error Correction Mechanism (ECM) is statistically significant and negative, which indicates the presence of cointegration/long-memory relationships between the variables in the study.

From the results, it is possible to observe that, in the short run, tourism intensity, capital investment, electric power consumption, and real exchange rate have a positive and significant impact on the economic growth of the Latin America and Caribbean countries, with the electric power consumption per capita being the main driver of the growth. In the long-run, all variables were shown to be significant and have a positive impact on growth. The tourism arrivals and electric power consumption have been revealed to be the principal drivers of economic growth in this region.

Therefore, the tourism intensity and capital investment, both on short and long-run, had a positive impact on the economic growth of the Latin America and Caribbean countries, which supports Hypotheses 1 and 2.

The main finding of this investigation is that once that tourism has a positive impact on the economic growth of this region, which means that an increase on the tourism intensity leads an increase on the economic growth, this region should increase the level of investment in this sector. The policymakers of the Latin America and Caribbean region should continue to develop measures aimed to attract as many tourists as possible while simultaneously promoting the investment in their travel and tourism industries. The country's economies have to invest more in human capital directly involved with the tourism sector and invest more in marketing to promote the region of Latin America and the Caribbean in addition to other economic sectors.

When a tourist chooses one destination, the majority of them (or all of them) do so considering the economic situation, the level of security, and the public health conditions of the region. Consequently, the policymakers should increase the level of the investments in healthcare (both to residents and tourists), which could happen through international partnerships with tourism agencies, for example, and should also increase the security in the region.

However, they also must pay attention to the other economic sectors so that their countries do not become extremely dependent on tourism activity. Excessive investment in the tourism sector, while neglecting the other sectors of the economy may lead these countries to a 'deindustrialisation' situation.

The use of energy consumption or electric power consumption directly related to tourism should be included in further research because it is a limitation of this investigation, as is the temporal horizon that ends in 2014. Another limitation of the study is analysing 
the exchange rate behaviour with on linear analysis, which is different from what is commonly addressed in the literature, non-linear methods (e.g., Dogru et al., 2019; Irandoust, 2019).

We note that another gap in the tourism literature and economic growth that may be incorporated in future research: the inclusion of exogenous variables representing instability (e.g., political instability). Thus, allowing a more robust empirical approach to the current problems of the countries of the region (e.g., Venezuela, Brazil, Argentina, Bolivia) could guarantee greater veracity of the results (e.g., Arslanturk et al., 2011; Chen \& Chiou-Wei, 2009).

\section{Acknowledgments}

CеBER, R\&D unit funded by national funds through FCT - Fundação para a Ciência e a Tecnologia, IP, project UIDB/05037/2020; NECE, R\&D unit funded by national funds through FCT - Fundação para a Ciência e a Tecnologia, IP, project UIDB/O4630/2020; CEFAGE, R\&D unit funded by national funds through FCT - Fundaçâo para a Ciência e a Tecnologia, IP, project UIDB/04007/ 2020 .

\section{References}

Aghion, P., Bacchetta, P., Rancière, R., \& Rogoff, K. (2009). Exchange rate volatility and productivity growth: The role of financial development. Journal of Monetary Economics, 56(4), 494-513.

Algieri, B. (2006). International tourism specialisation of small countries. International Journal of Tourism Research, 8(1), 1-12.

Al-mulali, U., Fereidouni, H. G., Lee, J. Y. M., \& Mohammed, A. H. (2014). Estimating the tourism-led growth hypothesis: A case study of the Middle East countries. Anatolia, 25(2), 290-298.

Amaghionyeodiwe, L. A. (2012). Research note: A causality analysis of tourism as a long-run economic growth factor in Jamaica. Tourism Economics, 18(5), 1125-1133.

Arslanturk, Y., Balcilar, M., \& Abidin, Z. (2011). Time-varying linkages between tourism receipts and economic growth in a small open economy. Economic Modelling, 28(1-2), 664-671.

Aslan, A. (2014). Tourism development and economic growth in the Mediterranean countries: Evidence from panel Granger causality tests. Current Issues in Tourism, 17(4), 363-372.
Balaguer, J., \& Cantavella-Jordá, M. (2002). Tourism as a long-run economic growth factor: The Spanish case. Applied Economics, 34(7), 877-884.

Belucio, M., Antunes, J., Fernandes, F., Fuinhas, J. A. \& Martin, M. B. L. (2018, November). Revisiting the tourism on Latin America: A panel analysis. Paper presented at SemeAd 2018 - xx I Seminário em Administração da Universidade de São Paulo.

Bianchi, C., Mingo, S., \& Fernandez, V. (2018). Strategic management in Latin America: Challenges in a changing world. Journal of Business Research, 105, 306-309.

Blake, A., Sinclair, M. T., \& Soria, J. A. C. (2006). Tourism productivity: Evidence from the United Kingdom. Annals of Tourism Research, 33(4), 1099-1120.

Brida, J. G., Cortes-Jimenez, I., \& Pulina, M. (2016). Has the tourism-led growth hypothesis been validated? A literature review. Current Issues in Tourism, 19(5), 394-430.

Brida, J. G., Lanzilotta, B., \& Pizzolon, F. (2016). Dynamic relationship between tourism and economic growth in MERCOSUR countries: A nonlinear approach based on asymmetric time series models. Economics Bulletin, 36(2), 879-894.

Brida, J. G., Lanzilotta, B., \& Risso, W. A. (2008). Turismo y crecimiento económico: El caso de Uruguay. Revista de Turismo y Patrimonio Cultural, 6(3), 481-492.

Cannonier, C., \& Burke, M. G. (2019). The economic growth impact of tourism in small island developing states - Evidence from the Caribbean. Tourism Economics, 25(1), 85108.

Cárdenas-García, P. J., Sánchez-Rivero, M., \& Pulido-Fernández, J. I. (2015). Does tourism growth influence economic development? Journal of Travel Research, 54(2), 206-221.

Chen, C., \& Chiou-wei, S. Z. (2009). Tourism expansion, tourism uncertainty and economic growth: New evidence from Taiwan and Korea. Tourism Management, $30(6), 812-818$.

Cortes-Jimenez, I., \& Pulina, M. (2010). Inbound tourism and long-run economic growth. Current Issues in Tourism, 13(1), 61-74.

Dogru, T., \& Bulut, U. (2018). Is tourism an engine for economic recovery? Tourism Management, 67, 425-434.

Dogru, T., Isik, C., \& Sirakaya-Turk, E. (2019). The balance of trade and exchange rates: Theory and contemporary evidence from tourism. Tourism Management, 74, 12-23.

Driscoll, J. C., \& Kraay, A. C. (1998). Consistent covariance matrix estimation with spatially dependent panel data. Review of Economics and Statistics, 8o(4), 549-560.

Du, D., Lew, A. A., \& Ng, P. T. (2016). Tourism and economic growth. Journal of Travel Research, 55 (4), 454-464. 
Durbarry, R. (2004). Tourism and economic growth: The case of mauritius. Tourism Economics, 10(4), 389-401.

Eugenio-Martin, J. L., Martín Morales, N., \& Scarpa, R. (2004). Tourism and economic growth in Latin American countries. SSRN Electronic Journal, 26, 1-28.

Fuinhas, J. A., \& Marques, A. C. (2012). Energy consumption and economic growth nexus in Portugal, Italy, Greece, Spain and Turkey. Energy Economics, 34(2), 511-517.

Garza, N., \& Ovalle, M. C. (2019). Tourism and housing prices in Santa Marta, Colombia: Spatial determinants and interactions. Habitat International, 87, 36-43.

Gunduz, L., \& Hatemi-J, A. (2005). Is the tourism-led growth hypothesis valid for Turkey? Applied Economics Letters, 12(8), 499-504.

Habib, M. M., Mileva, E., \& Stracca, L. (2017). The real exchange rate and economic growth: Revisiting the case using external instruments. Journal of International Money and Finance, 73(1), 386-398.

Hatemi-J, A., \& Irandoust, M. (2005). Energy consumption and economic growth in Sweden: A leveraged bootstrap approach (1965-2000). International Journal of Applied Econometrics and Quantitative Studies, 2(4), 87-98.

Holzner, M. (2011). Tourism and economic development? The beach disease? Tourism Management, 32(4), 922933.

Husein, J., \& Kara, S. M. (2011). Research note: Re-examining the tourism-led growth hypothesis for Turkey. Tourism Economics, 17(4), 917-924.

International Monetary Fund. (2018, 16 July). World economic outlook update. https:/www.imf.org/en/ Publications/WEO/Issues/2018/o7/o2/world-economic -outlook-update-july-2018

Irandoust, M. (2019). On the relation between exchange rates and tourism demand: A nonlinear and asymmetric analysis. The Journal of Economic Asymmetries, 20, 1-10.

Jouini, T. (2015). Efficient multistep forecast procedures for multivariate time series. Journal of Forecasting, 34(7), 604-618.

Katircioglu, S. T. (2009). Revisiting the tourism-led-growth hypothesis for Turkey using the bounds test and Johansen approach for cointegration. Tourism Management, 3o(1), 17-20.

Lanza, A., \& Pigliaru, F. (200o). Tourism and economic growth: Does country's size matter? Rivista internazionale di scienze economiche e commerciali, 47, 77-85.

Lee, C. C., \& Chang, C. P. (2008). Tourism development and economic growth: A closer look at panels. Tourism management, 29(1), 180-192.

Malaquias, R., Borges Junior, D., Malaquias, F., \& Albertin,
A. (2019). Climate protection or corporate promotion? Energy companies, development, and sustainability reports in Latin America. Energy Research \& Social Science, 54, 150-156.

Malta, G. A. P., Braga, S. S., \& Barbosa, M. F. P. (2019). Conceptions of economic development and the understanding of the role of tourism in poverty reduction. Brazilian Journal of Tourism Research, 13(2), 16-31.

Marques, L. M., Fuinhas, J. A., \& Marques, A. C. (2017). Augmented energy-growth nexus: economic, political and social globalization impacts. Energy Procedia, 136, 97101.

Massidda, C., \& Mattana, P. (2013). A svecm analysis of the relationship between international tourism arrivals, GDP and trade in Italy. Journal of Travel Research, 52(1), 93-105.

Maximiliano, K. (2014). Problems of tourism safety in Latin America: Foreword two. In P. E. Tarlow (Ed.), Tourism security: Strategies for effectively managing travel risk and safety (pp. xxi-xxiv). Butterworth-Heinemann.

Menegaki, A. N., Marques, A. C., \& Fuinhas, J. A. (2017). Redefining the energy-growth nexus with an index for sustainable economic welfare in Europe. Energy, 141, 12541268.

Nissan, E., Galindo, M. A., \& Méndez, M. T. (2011). Relationship between tourism and economic growth. Service Industries Journal, 31(10), 1567-1572.

Özokcu, S., \& Özdemir, Ö. (2017). Economic growth, energy, and environmental Kuznets curve. Renewable and Sustainable Energy Reviews, 72, 639-647.

Payne, J. E., \& Mervar, A. (2010). Research note: The tourismgrowth nexus in Croatia. Tourism Economics, 16(4), 1089-1094.

Pesaran, M. H. (2007). A simple panel unit root test in the presence of cross-section dependence. Journal of Applied Econometrics, 22(2), 265-312.

Risso, W. A., \& Brida, J. G. (2008). The contribution of tourism to economic growth: An empirical analysis for the case of Chile. European Journal of Tourism Research, $2(2), 178-185$.

Rivera, M. A. (2017). The synergies between human development, economic growth, and tourism within a developing country: An empirical model for ecuador. Journal of Destination Marketing and Management, 6(3), 221-232.

Santiago, R., Fuinhas, J. A., \& Marques, A. C. (2020). The impact of globalization and economic freedom on economic growth: The case of the Latin America and Caribbean countries. Economic Change and Restructuring, $53(1), 61-85$. 
Shahzad, S. J. H., Shahbaz, M., Ferrer, R., \& Kumar, R. R. (2017). Tourism-led growth hypothesis in the top ten tourist destinations: New evidence using the quantileon-quantile approach. Tourism Management, 60, 223232.

Suárez, J. A., Beatón, P. A., Escalona, R. F., \& Montero, O. P. (2012). Energy, environment and development in Cuba. Renewable and Sustainable Energy Reviews, 16(5), 27242731.

Tang, C. F., \& Abosedra, S. (2014). The impacts of tourism, energy consumption and political instability on economic growth in the MENA countries. Energy Policy, 68, 458-464.

Tang, C. H., \& Shawn, S. (2009). The tourism - Economy causality in the United States? A sub-industry level examination. Tourism Management, 3o(4), 553-558.

Toman, M. T., \& Jemelkova, B. (2003). Energy and economic development: An assessment of the state of knowledge. The Energy Journal, 24(4), 93-112.
Tugcu, C. T. (2014). Tourism and economic growth nexus revisited: A panel causality analysis for the case of the Mediterranean Region. Tourism Management, 42, 207212.

World Tourism Organization. (2015). Annual Report 2015. https://www2.unwto.org/sites/all/files/pdf/annual _report_2015_lr.pdf

World Travel Market. (2018, 26 June). México, Brasil e Argentina São os Países Mais Visitados na América Latina. https://news.wtm.com/pt/mexico-brasil-e-argentina -sao-os-paises-mais-visitados-na-america-latina/

World Travel \& Tourism Council. (2018). Caribbean recovery. https://www.wttc.org/priorities/crisis-preparedness /caribbean-recovery/

Zortuk, M. (2009). Economic impact of tourism on Turkey's economy: Evidence from co-integration tests. International Research Journal of Finance and Economics, 1(25), 231-239. 